HStud 27 (2013)2, 251-261

DOI: 10.1556/HStud.27.2013.2.4

\title{
TOWNS, VILLAGES, DEPOPULATED SETTLEMENTS - POPULATION MOVEMENTS IN OTTOMAN HUNGARY
}

\author{
GÉZA DÁVID \\ Eötvös Loránd University, Budapest, Hungary \\ E-mail: davidgeza@hotmail.com
}

\begin{abstract}
The demographic history of Hungary is full with question marks, mainly due to the lack of reliable sources until the end of the $18^{\text {th }}$ century. Especially, the number of the population throughout the Ottoman period (1521-1718) constituted a 'black hole' for a long period of time and related issues were characterized by a great number of unfounded clichés and prejudices. Identifying the best Turkish and Habsburg archival documents containing more or less detailed data on tax-payers or houses and using estimations for Transylvania where such material is missing, one can establish the total number of the population of the country at the end of the $16^{\text {th }}$ century with considerable accuracy, give details about the ratios of town and village people, characterize the average number of inhabitants in rural settlements and as a whole on one $\mathrm{km}^{2}$, the proportion of depopulated villages, the ethnic composition of certain areas and occasionally even follow migration patterns between the 1540s and 1590. Unfortunately, almost no usable registers were prepared during the $17^{\text {th }}$ century; therefore this time span will always remain a terra incognita, only estimations can be ventured regarding the number of inhabitants around 1700 .
\end{abstract}

Keywords: towns, villages, population movements, migration, ethnic changes, Ottoman Hungary, Hungarian Kingdom

The demographic history of Hungary is full with mysteries and question marks at least until the end of the $18^{\text {th }}$ century when the first official census was prepared. We do not know - among other things - how many people arrived with chieftain Árpád to the Carpathian Basin at the end of the $9^{\text {th }}$ century and how many and what sort of earlier settlers they found there. Regarding Árpád's folk, a figure mentioned by more or less contemporary, partly disappeared Arabic sources has been used as the basis of computation, according to which he had a military force of 20,000 horsemen. Knowing that even today it is quite difficult to establish the quantity of participants at a demonstration (and organizers give five times higher values than the other party), the reliability of such a round number from the $10^{\text {th }}$ century is highly questionable. I even venture to think that if any of the estimated totals for the population of Hungary around 900 (Kovacsics, 1997, 14, 21, 22; 
Kristó, 2007, 18) is more or less correct, it is almost independently so from the value given by the Arabic sources. The situation is not much better after hundreds of years, although we have more data but they are usually sporadic.

In this connection it seems appropriate to quote T. H. Hollingsworth (1969, 12), an influential author in the field of historical demography, who gave the following characterization concerning the reliability of population data before the modern period in general: "And all historical arguments are more or less weak, for no one can ever be totally certain or totally uncertain of anything." (This sentence is not completely accurate, to state, for instance, that the population of Hungary was either 5 or 10 million or 5 or 10 thousand around 1000, is nonsense.) He is, however, right in saying that: "The degrees of certainty run from 'sure' to 'very likely' to 'probable', to 'possible', and on through 'unproved', and 'rather unlikely' to 'presumably wrong' and 'wrong'."

Hollingsworth is basically right as far as ambiguities are concerned: Even in the case of countries which had a considerably more peaceful history than Hungary, and where parish registers, which are the best sources of demographic studies for centuries, had been introduced much earlier, it is quite difficult to give reasonably exact figures concerning several demographic aspects not to speak of the total number of the population.

Our present issue is even more intricate since we are going to deal with a very turbulent period of Hungary, overshadowed by wars, in the $16^{\text {th }}$ and $17^{\text {th }}$ centuries. Therefore the results which can and will be presented here are often tentative and reach the level 'possible' or 'probable' at the best on the above-mentioned scale.

One of the basic questions, of course, is the quantity and reliability of extant sources. This is not the place to introduce them one by one. Let it be enough to say that the best types of them are tax/land registers on both sides. These are comparatively numerous in the $16^{\text {th }}$ century but they almost fully disappear or lose their source value by the $17^{\text {th }}$ century, which is, of course, a serious handicap. On the Ottoman side one can rely on the detailed defters of the sub-provinces (sancaks) and a head-tax list of the province (vilayet) of Buda from 1577-78 (Dávid, G., 2007, 137-40). Within the Habsburg sources by far the most complete is the house-register of 1598 (Dávid, Z., 2001). Regarding Transylvania we have much fewer similar data (Dávid, Z., 1997, 17-22; Draskóczy, 2007).

Needless to say, none of these surveys can match a modern census (of which Fernand Braudel $(1975,2)$ stated that they also suffer from deficiencies amounting to 10 per cent or so). These lists were prepared for taxation purposes, and since nobody likes to pay taxes, there have always been attempts to remain outside such rolls. Consequently the danger of under-registration is always present. In spite of this, as we shall see, some of the Ottoman defters contain surprisingly minor details about the population. 
From the point of view of settlement networks or historical geography and also historical demography, the great problem with the Ottoman registers in Asia Minor and the Balkans is that fairly often there is almost no possibility of checking the validity of data preserved in them. Ottoman Hungary is in a much more favourable position in this respect. We have some 500,000 documents from before 1526 and several tax registers from the period before 1541. These contain among other things - so many place names that the medieval network of settlements could be reconstructed with high accuracy even in most of those counties which were in Ottoman hands. The four-volume historical geography by Dezső Csánki (1890-1914) which is complemented by other works is a very useful tool for everybody trying to identify place-names mentioned in the Ottoman lists. It is to be emphasized that with the help of relevant works on historical geography of Hungary, all the towns and most of the villages (more than 90 per cent) figuring in the defters can be identified, and not rarely even uninhabited places. (As a contrast, in the sancak of Akşehir, situated between Eskişehir and Konya in central Anatolia, one could find merely 42 villages with the same and 20 others with changed names out of 155 registered in the $16^{\text {th }}$ century, which gives a low ratio of 40 per cent (Ertürk, 2011, 45).

Issues of population number and movements have belonged to one of the most heatedly debated topics concerning Ottoman Hungary and the ones characterized by several, often erroneous, commonplaces. Many authors dealing with these questions based their argumentation on observations of contemporary travelers or exclusively on data coming from Habsburg tax-lists thus arriving at rather negative and discouraging results. Large numbers of burned up and depopulated villages, seriously decreasing population, hundreds of thousands of captives driven out of the country are typical elements of this depressive picture. (I have to add: not only in Hungary; a recent American book asserts that Süleyman left Hungary after the Battle of Mohács with 105,000 captives (Watts, 2012) obviously a gross exaggeration; also technically and physically impossible; think of feeding them during the long route home. We can find the same figure in the entry Hungarian Turkish War 1521-1526, in the Encyclopedia of Wars, 584. Both works go probably back to the $11^{\text {th }}$ edition of the Encyclopaedia Britannica, published in 1911, more than 100 years ago!)

Population loss seemed to be considerably high because estimations for the end of the $15^{\text {th }}$ century, when we have the first set of data for almost the whole country, were too optimistic, and since they were made by a very careful historian of good reputation, they have not been disputed for decades. Accordingly, Hungary had some 3.5-4 million inhabitants around 1494-95 (Szabó, 1963, 97-8). Later research, however, revealed that his equation of one taxation unit in the list with two families, is open to doubt (Solymosi, 1984), therefore his figures are too high, at 
least in several counties. Consequently the more realistic value should be around 3-3.2 million (Fügedi, 1992, 41; Kubinyi, 1996, 153).

If we wish to come to a conclusion about the population of Hungary in the Ottoman times we also have to know the extension of the three parts into which medieval Hungary was split into. This extension changed several times. Moreover semi-official or military boundaries were not necessarily the same as the line until which the respective side was practically able to prepare an almost full list of its tax paying inhabitants - this turns out from the analysis and comparison of the sources of both (Habsburg and Ottoman) parties. At the end of the $16^{\text {th }}$ century, when we have the best population data, the relevant parts can be characterized with the following territorial size and number of inhabitants (Dávid, G., 2007, 141-2, 145-7):

Ottoman Hungary covered $120,000 \mathrm{~km}^{2}$, roughly $47,000 \mathrm{mi}^{2}$. There lived some 850,000 Christians and approximately 50,000 Muslims, altogether 900,000 souls here. (We have to emphasize that earlier estimates gave half of this value due to the fact that less reliable data and less expedient methods were used when calculating them (Bakács, 1963, 133).) Rests of the Hungarian Kingdom also had an extension of approximately $120,000 \mathrm{~km}^{2}$, once again nearly $47,000 \mathrm{mi}^{2}$, with some 1,800,000 inhabitants. Transylvania was smaller, only some $60,000 \mathrm{~km}^{2}$, or $23,500 \mathrm{mi}^{2}$, with circa 800,000 inhabitants.

This means that the total population of the country amounted to 3.5 million at the end of the $16^{\text {th }}$ century. This value testifies to a modest population increase in the country within 100 years, mainly in Habsburg Hungary and to a lesser extent in Transylvania. In Ottoman Hungary we have to reckon with population decrease in the periods of warfare and stagnation with slow recovery in more peaceful times and areas.

It can be remarked here that the two confronting areas were quite militarized. On the Habsburg side the ratio of garrison troops was over 1 per cent of the total population and this proportion was nearly the double - including the timariots on the Ottoman front line. A comparison with early $18^{\text {th }}$-century standing armies in Austria and France, constituting 1.25 and 2 per cent of the total population, respectively, renders the Ottoman ratio over 2 per cent in the defense zone quite considerable (Dávid, G., 2013, 300).

Regarding the end of the $17^{\text {th }}$ century, as I have referred to it, our knowledge is much more limited. It seems undisputable that primary data from both the Ottoman and Habsburg sources after 1590 and 1598, respectively, cannot be used to draw conclusions of demographic relevance. Notably, after 1608, one "porta" was legally equal with 4 serfs with land or 12 villains without land. Parallel to this practice, head-tax units on Ottoman territories - similarly to the extraordinary levy units (avarz hanes) - were composed of several families ranging from 3 to 20 households in the $17^{\text {th }}$ century (Hegyi, 376-7), which resulted in serious de- 
crease of totals either on settlement or on district level in the relevant tax-registers. These, however, should not be taken at face value, and if they show anything, it is the economic strength of the place or region in question (Dávid, Z., 1993). What remains, is to make estimation backwards on the basis of the first census of 1784-87. We can say that the population of Ottoman Hungary, on a somewhat more extended territory, must have been approximately 1,000,000 persons, that of Habsburg Hungary around 2,100,000 and that of Transylvania some 900,000. Thus we reach a total of 4 million people around 1700 which means a modest increase again (Dávid, G., 2007, 173).

Coming to urban and village population, it can be maintained that by the time of the Ottoman occupation, a rather large network of urban and semi-urban places had developed in Hungary, though on a lower level of urbanization than their Western European counterparts. Legal practice differentiated two types of towns, called civitas ("free royal town") and oppidum ("market town" or German: Marktflecken), respectively. The number of settlements belonging to the first group was rather low until the Ottoman period; of them merely four were occupied in the $16^{\text {th }}$ century (Buda, Pest, Székesfehérvár, and Esztergom). The second category was much more numerous; some of them had considerably larger population than royal towns but they lacked city-walls in compliance with their official status. Many of them fell under Ottoman rule.

An often discussed question after 1945 was trends of (semi-) urban development. Some scholars claimed that progress was uninterrupted until the Ottoman period and only their rule stroke a blow at it. Others argued that stagnation started a bit earlier, namely at the beginning of the $16^{\text {th }}$ century due to local and international reasons. The testimony of the Ottoman registers seems to corroborate the second view. The argumentation runs as follows: since the Turkish scribes faithfully followed their local informants in categorizing the settlements' legal status, a decrease in the number of towns and market towns would prove that the set-back in urbanization had started before the Ottomans made their first surveys. Former calculations arrived at 750 oppida in Hungary (without Transylvania and Slavonia) in the second half of the $15^{\text {th }}$ century. Half of the territory concerned came into Ottoman possession. On that part of the country some 225-250 (out of them 170-180 being situated on the territory of modern Hungary) settlements were regularly designated as towns in the Turkish surveys throughout the $16^{\text {th }}$ century. In Habsburg Hungary 122 places were entered as towns into the house registration of 1598 which clearly shows the enormous decrease in the number of market towns also in the northern regions for which the Ottomans cannot be made responsible. This result first leads us to the conclusion that the above-cited value for the number of urban settlements at the late Middle Ages must be unacceptable; in all likelihood it was gained by adding up all of the related data from the $15^{\text {th }}$ century without trying to check their contemporaneousness. At the same time, it 
also indicates that the oppidum-status had lost its prestige for a number of settlements (for more details and literature see Dávid, G., 1995, 332; Dávid, G., 2007, 149).

Earlier researchers made efforts to give an approximate value for the proportions of urban and semi-urban population. Counting with the above-mentioned high quantity of oppida, a ratio between 16 and 20 per cent was achieved (Szabó, 1971, 197). Using the Ottoman registers, it became evident that out of 67,000 Christian heads of families in 15 administrative units in the provinces of Buda and Temesvár, some 15,000 (more than 22 per cent) lived in towns and market towns around 1568-80. If Muslims were added, this value would be even higher since these latter almost exclusively lived in castles. By and large the same high ratio can be obtained for Habsburg Hungary in 1598, which implies that the average size of towns grew within 100 years. The negative aspect of the matter is that almost no urban settlements could uninterruptedly develop in the Ottoman zone, just on the contrary: after promising rises, sudden drops can be witnessed. It cannot always be clearly established what caused the sudden decay of seemingly flourishing places. Many of the towns belonging to the most unfortunate group were administrative and/or military centers from where the original population fled sooner or later. It can be also supposed that places specializing in wine-production were more vulnerable than those where the major occupation was cattle-breading or wheat-growing, but under-registration also comes to mind at least as far as 1590 is concerned, when most of the sudden drops are observed. It is perhaps unexpected that the largest decrease took place in a seemingly peaceful, small sub-province around Szekszárd with more than 50 per cent town population in 1565 of which more than the half had disappeared by 1590 . In contrast to this sub-province, we see a mere 12 per cent loss among Hungarians in the urban settlements of the provincial centre, Buda (Dávid, G., 1995, 339, table 2). Unfortunately, I cannot find a good explanation for the difference.

To give an impression about the largeness of urban centers north of the river Dráva: the largest towns had some 10,000 inhabitants at least for a period of time during their $16^{\text {th }}$ century history; there were three of them (Kecskemét, Szeged and Tolna). If we consider that almost none of $15^{\text {th }}$ century Hungarian towns appear to have been dwelt by 7 to 10,000 persons we shall better appreciate these values. Further, we find 11 towns with more than 400 families in one of the registers; this means a minimum of 3,000 inhabitants. Most of the places in question had purely Hungarian residents. With their over 2,000 (later somewhat fewer) Ottoman soldiers each, the three former governing and ecclesiastic centers, Buda, Esztergom and Székesfehérvár can also be added to this category.

Then we have places with more than 100 and less than 400 registered taxpayers; this group includes 34 settlements. Some of them, especially those in the sancak of Temesvár, were almost unknown to Hungarian historiography - their 
first population data come from the Turkish sources. Some further settlements occasionally also show up values over 100 heads of families but later they become insignificant, therefore they were left out from the above figure. Lastly, "towns" with less than 100 married men form a group with some places having just a few houses or having lost almost completely their original settlers with the passing of time.

What can be said about the distribution of towns in Ottoman Hungary? Disregarding the regions south of Lake Balaton and to the east, south-east of the river Tisza, a network of towns of considerable size can be detected, undoubtedly of medieval origin. Another peculiarity of the geographical location is that many of these towns were founded near rivers. The importance of rivers as transportation facilities, as grinding, crawling and fishing potential is well-known - even our example supports the rule.

Arriving at this point we can mention that András Kubinyi (2000), the best authority of late $15^{\text {th }}$ century Hungarian history, has worked out a set of criteria in order to establish the real importance of towns in medieval Hungary. He gave from one to six points to all the urban settlements from 10 different aspects. Following his approach we can also try to find certain, clearly significantly less, decisive factors which could help us construct a relative hierarchy among urban settlements in Ottoman Hungary which list could be compared with Kubinyi's results for previous times and we could see which towns preserved their eminence and which sank back in the hierarchy or lost their significance altogether.

Which could be these criteria? Besides the number of the population, we can easily decide if the place was an administrative center (seat of a province, a sub-province or a district) or a Muslim religious focal point (with a kadi-court, a cami/mosque or a mescid/smaller mosque, a türbe/mausoleum, a bath, a pious foundation or a dervish lodge). We can also locate all the castles and fortifications with a regular military force - the number of soldiers can also modify the rank of the place. We have short but useful entries concerning local weekly markets and larger fairs "standing" only once, twice or three times a year. River ports, bridges or crossing points are somewhat less habitually mentioned. As regards main roads and those of secondary importance and the number of places which one could directly reach from a town, data can be - in all likelihood - taken over from Kubinyi's work since there was no significant change in this respect. (It is another question that primary routes of cattle trade were modified.) Much less information can be collected for surviving Christian ecclesiastic buildings and activities and about functioning guilds. Slaughterhouses should probably be also added to our criteria since they exclusively appear in towns. I have no doubt that in spite of its considerably modest population Buda will be on the first place as a result of such an investigation. It is more difficult to guess the sequence of the rest of the settlements in question. 
As for the villages, we can posit that in principle they were more vulnerable in periods of war than towns. Therefore one would expect that the average population of villages under Ottoman rule showed a decreasing tendency as compared to the same indicator in the $15^{\text {th }}$ century. Against this anticipation we find that average village size grew both in Ottoman and Habsburg Hungary. We have the following values: At the end of the $15^{\text {th }}$ century there lived 120 persons per village in the country. In Ottoman Hungary we have 140 persons per village (this average was attained in 2,300 settlements). In Habsburg Hungary we find approximately 150 persons per village.

If we look at population density, however, we observe a significant difference between Habsburg and Ottoman Hungary. While on the Habsburg territories 15 persons lived on one $\mathrm{km}^{2}$, this indicator was only seven and a half in the Ottoman regions. The great dissimilarity is partly due to geographical factors and previous developments.

The most persistent clichés in the field of demography can be read concerning depopulation in Hungary. Again, especially people dealing with local history are apt to give credit even to the least reliable data in this respect. The Ottoman sources once again shed light on certain features of this important issue.

Accordingly, after a short period of non-negligible losses, when nearly 20 per cent of the villages became empty, an almost undisturbed epoch followed, with insignificant damages in the settlement structure (Dávid, G., 1974; 2007, 159). This observation, however, is valid only for territories in modern Hungary, while other regions, chiefly those south of the Danube-Dráva line suffered a much more serious decay of inhabited places, occasionally amounting to 70-75 per cent (Engel, 2000). It is a rather difficult task to find out the date of depopulation of places which disappear from the map during the $17^{\text {th }}$ century; the so-called "wars of liberation" are often blamed for their losses (while the Rákóczi war of independence between 1703-11 is usually forgotten as a possible factor).

Another aspect of population movements is migration, which is getting more and more importance in our present age (think merely of immigrants from Mexico to the USA and from Muslim countries to Europe) but had considerable significance in earlier epochs, too (for examples in the Ottoman Empire see: Barkan, 1950, 1952, 1954; Schütz, 1988; Emecen, 1994). It is quite difficult to follow the migratory tendencies in the $16^{\text {th }}$ century in general and also on the Ottoman territories. Exceptionally, an inquiry in this direction is possible in the sub-province of Buda between 1546 and 1559. One of the surprising results of this examination is that merely 6 persons moved to a place in Habsburg Hungary. The second interesting message of the pertinent data is that 75 per cent of the migrants moved to the nearest village or town (for details see: Dávid, G., 1991). One would have expected considerably more people to escape from the allegedly insecure, war stricken, and chaotic region. 
Conversion from Christianity to Islam was an extremely rare phenomenon in Ottoman Hungary. We know just a few garrison soldiers and even fewer persons from among the ranks of the nobility. Another small, this time Orthodox, group of renegades can be demonstrated in the sub-province Szeged, where one regularly encounters one single Muslim in each village while the rest of the inhabitants are Christians without exception (Halasi-Kun, 1964). In our interpretation, the sincerity of conversion can be questioned with good reason in such cases and the real motivation behind it must have been a practical consideration: it was hoped that a Muslim in the community had better positions in bargaining with the Ottoman officials (Dávid, G., 2001, 154).

My last words are about changes in the ethnic composition of the population of Hungary in the Ottoman period which are closely related to migrants in various epochs. Again, we have no exact figures from before 1526. However, it seems undeniable that the ratio of Hungarians had diminished by the second half or the end of the $16^{\text {th }}$ century. At this point, as it can be inferred from the defters, some 60 per cent of the 900,000 people were Hungarians, the rest were first of all Southern-Slavs, then Muslims of various origin (just a few real Turks), Slovaks, and Romanians. It is perhaps useless to mention that in the central parts almost everybody was Hungarian (except for the Muslims), while the other ethnic groups lived in a belt around the kernel parts. The diminishing ratio of Hungarians within the Carpathian Basin was characteristic of the rest of the country as well: within 200 years their proportion sank from $65-70$ per cent to 50 per cent. If we want to postulate no numerical loss within this community by 1700, when 2 million Hungarians can be estimated, we have to reckon with a starting population of 3 million, and two thirds of Hungarians among them, in 1494-95. Even in this case, some 666,000 persons are missing (who not necessarily died but partly could not be born as a result of early losses) so as to represent the original proportion. This clearly indicates that the Hungarian element suffered the most during the Ottoman times, especially before the real occupation of the southern regions from where it disappeared altogether (Dávid, G., 2007, 172-3). In other words it can be concluded that in spite of certain positive tendencies, the final outcome of the Ottoman period was the diminishing of the Hungarian community which had long-lasting, from its own point of view negative effects.

\section{References}

Bakács, István, 1963. A török hódoltság korának népessége [The Population of the Era of the Turkish Occupation]. In: József Kovacsics, ed. Magyarország történeti demográfiája. Magyarország népessége a honfoglalástól 1949-ig [The Historical Demography of Hungary. Hungary's Demography from the Conquest until 1949]. Budapest: Közigazgatási és Jogi Könyvkiadó, 115-142. 
Barkan, Ömer Lütfi, 1950, 1952, 1954. Osmanlı İmparatorluğu'nda bir iskân ve kolonizasyon metodu olarak Sürgünler. İstanbul Üniversitesi İktisat Fakültesi Mecmuas1, 11, 524-61, 13, 56-78, 15, 209-37.

Braudel, Fernand, 1975. Capitalism and Material Life 1400-1800. New York, Hagerstown, San Francisco, London: Harper Colophon Books.

Csánki, Dezső, 1890-1913. Magyarország történelmi földrajza a Hunyadiak korában [The Historical Geography of Hungary in the Hunyadi Era] I-III, V. Budapest, 1890-1913.

Dávid, Géza, 1974. Some Aspects of $16^{\text {th }}$ Century Depopulation in the Sanǰa $q$ of Simontornya. Acta Orientalia Academiae Scientiarum Hungaricae, 28 (1), 63-74.

Dávid, Géza, 1991. Data on the Continuity and Migration of the Population in $16^{\text {th }}$ Century Ottoman Hungary. Acta Orientalia Academiae Scientiarum Hungaricae, 46 (2-3), 219-252.

Dávid, Géza, 1995. Demographic Trends of Urban Population in $16^{\text {th }}$ Century Ottoman Hungary. In: Daniel Panzac, ed. Histoire économique et sociale de l'Empire ottoman et de la Turquie (1326-1960). Actes du sixième congrès international tenu à Aix-en-Provence du $1^{\text {er }}$ au 4 juillet 1992. (Collection Turcica, VIII.) Paris: Peteers, 331-340.

Dávid, Géza, 2001. Limitations of Conversion: Muslims and Christians in the Balkans in the Sixteenth Century. In: E. Andor and I. Gy. Tóth, eds. Frontiers of Faith. Religious Exchange and the Constitution of Religious Identities, 1400-1750. Budapest: Central European University, European Science Foundation, 2001, 149-156.

Dávid, Géza, 2007. Die Bevölkerung Ungarns im 16.-17. Jahrhundert. Historische Demographie Ungarns (896-1996). (Studien zur Geschichte Ungarns, 11.) Herne: Gabriele Schäfer Verlag, $135-180$

Dávid, Géza, 2013. Ottoman Armies and Warfare, 1453-1603. In: Suraiya N. Faroqhi and Kate Fleet, eds. The Cambridge History of Turkey. II. The Ottoman Empire as a World Power, 1453-1603. Cambridge: Cambridge University Press, 276-319.

Dávid, Zoltán, 1993. Adatok a török háborúk pusztításának értékeléséhez [Data on the Destruction of the Turkish Wars]. Keletkutatás, 1993 (2), 56-68.

Dávid, Zoltán, 1997. A székelyek száma, 1567-1992 [The Number of the Székelys, 1567-1992]. In: A KSH Népességtudományi Kutató Intézet történeti demográfiai füzetei [Historical Demographical Booklets of the Demographic Research Institute of the Central Statistical Office] 16. Budapest: Központi Statisztikai Hivatal Népességtudományi Kutató Intézet, 7-74.

Dávid, Zoltán, 2001. Az 1598. évi házösszeírás [The Census of 1598]. Budapest: Központi Statisztikai Hivatal Levéltára.

Draskóczy, István, 2007. Die demographische Lage des Sachsenlandes zu Beginn des 16. Jahrhunderts. In: Historische Demographie Ungarns (896-1996). (Studien zur Geschichte Ungarns, 11.) Herne: Gabriele Schäfer Verlag, 94-134.

Emecen, Feridun, 1994. The History of Early Sixteenth Century Migration - Sirem exiles in Gallipoli. 77-91. In: Géza Dávid and Pál Fodor, eds. Hungarian-Ottoman Military and Diplomatic Relations in the Age of Süleyman the Magnificent. Budapest: Eötvös Loránd University, Department of Turkish Studies - Hungarian Academy of Sciences, Institute of History.

Engel, Pál, 2000. A török dúlások hatása a népességre: Valkómegye példája [The Influence of the Turkish Raids on Demographics: The Example of Valkó County]. Századok, 134 (2), 267-321.

Ertürk, Volkan, 2011. XVI. yüzyılda Akşehir sancă̆ı. İstanbul: Ati Yayınları.

Fügedi, Erik, 1992. A középkori Magyarország történeti demográfiája [The Historical Demography of Hungary in the Middle Ages]. In: A KSH Népességtudományi Kutatóintézetének Történeti Demográfiai Füzetei [Historical Demographical Booklets of the Demographic Research Institute of the Central Statistical Office] 10. Budapest: Központi Statisztikai Hivatal Népességtudományi Kutató Intézet, 7-60.

Halasi-Kun, T., 1964. Sixteenth-century Turkish Settlements in Hungary. Belleten, 28 (1), 1-72. 
Hegyi, Klára, 1983. A török birodalom magyarországi jövedelemforrásai [Sources of Income of the Turkish Empire in Hungary]. Századok, 117 (2), 346-383.

Hollingsworth, T. H., 1969. Historical Demography. Ithaca, New York: Cornell University Press. Hungarian Turkish War (1521-1526), 2005. In: Charles Phillips and Alan Axelrod, eds. Encyclopedia of Wars. Volume II. New York: Facts On File, 584. Available at: http://do.rulitru.ru/ docs/18/17594/conv_1/file1.pdf [Accessed May 10 ${ }^{\text {th }}$, 2013].

Kovacsics, József, 1997. A történeti demográfia válaszai és nyitott kérdései az Árpád-kori népesség számára vonatkozóan [Answers and Open Questions of Historical Demography with Regards to the Population Numbers of the Árpád Era]. In: József Kovacsics, ed. Magyarország történeti demográfiája. Millecentenáriumi elöadások [Hungary’ Historical Demography. Millennial Presentations]. Budapest: Központi Statisztikai Hivatal, 11-30.

Kristó, Gyula, 2007. Die Bevölkerungszahl Ungarns in der Arpadenzeit. In: Historische Demographie Ungarns (896-1996). (Studien zur Geschichte Ungarns, 11.) Herne: Gabriele Schäfer Verlag, 9-56.

Kubinyi, András, 1996. A Magyar Királyság népessége a 15. század végén [The Population of the Hungarian Kingdom at the End of the $15^{\text {th }}$ Century]. Történelmi Szemle, 1996 (2-3), 135-161.

Kubinyi, András, 2000. Városok, mezővárosok és központi helyek az Alföldön és az Alföld szélén [Cities, Market Towns, and Centers in the Alföld and its Peripheries]. In: Városfejlödés és városhálózat a középkori Alföldön és az Alföld szélén [Urban Development and Urban Networks in the Alföld of the Middle Ages]. Szeged: Csongrád Megyei Levéltár, 7-101 (Dél-alföldi évszázadok 14).

R. N. B.; W. A. P., 1911. Hungary. In: Encyclopaedia Britannica. Volume XIII. $11^{\text {th }}$ ed. Cambridge-New York: Cambridge University Press, 910. Available at: http://eb11.co.uk/index.php?p=HUNGARY38964-h.htm [Accessed May 10 ${ }^{\text {th }}, 2013$ ].

Schütz, Ödön, 1988. Örmények kitelepítése Perzsiába. Az 1640-es "nagy szürgün”, örmény források alapján [The Deportation of Armenians to Persia. The Great "Sürgün" of 1640 on the basis of Armenian Sources]. Keletkutatás, 1988 (2), 50-66.

Solymosi, László, 1984. Veszprém megye 1488. évi adólajstroma és az Ernuszt-féle megyei adószámadások [1488 Tax Registries of Veszprém County and the County Tax Accounts under János Ernuszt]. In: László Kredics, ed. Tanulmányok Veszprém megye múltjából [Essays on the History of Veszprém County]. Veszprém: Veszprém Megyei Levéltár, 121-239.

Szabó, István, 1963. Magyarország népessége az 1330-as és az 1526-os évek között [The Population of Hungary between the 1330s and 1526]. In: József Kovacsics, ed. Magyarország történeti demográfiája. Magyarország népessége a honfoglalástól 1949-ig [The Historical Demography of Hungary. Hungary's Demography from the Conquest until 1949]. Budapest: Közigazgatási és Jogi Könyvkiadó, 63-113.

Szabó, István, 1971. A falurendszer kialakulása Magyarországon (X-XV. század) [The Development of the System of Villages in Hungary (from the $10^{\text {th }}$ Century to the $15^{\text {th }}$ Century]. $2^{\text {nd }}$ ed. Budapest: Akadémiai Kiadó.

Watts, Tim, 2012. The Battle of Mohács. In: Frank W. Thackeray and John E. Findline, eds. Events that Formed the Modern World. Volume I. From the European Renaissance to the War on Terror. Santa Barbara, CA: ABC-CLIO, LLC. No page numbering. Available at: http://books. google.hu/books?id=O2MhulpUa_cC\&printsec=frontcover \&dq= $\% 22$ Thackeray $\% 22 \% 22$ Find line $\% 22 \& \mathrm{hl}=$ hu\&sa $=$ X\&ei $=$ damOUey6POGF4ASgmIGAAw\&ved=0CCMQ6AEwAA\#v $=$ on epage $\& \mathrm{q}=$ captives $\& \mathrm{f}=$ false $\left[\right.$ Accessed May $\left.10^{\text {th }}, 2013\right]$. 